УДК 336.717.061.1

DOI $10.21661 / \mathrm{r}-130110$

\title{
С.В. Илюхина
}

\section{ОСОБЕННОСТИ СЕЛЬСКОХОЗЯЙСТВЕННОГО КРЕДИТОВАНИЯ В СВЕРДЛОВСКОЙ ОБЛАСТИ}

Аннотация: в данной статье обосновывается политика сбалансированного развития села на основе программ поддержки кредитования сельхозпроизводителей. Представлень результаты анализа данных по прибыли, займам и кредитам 74 сельскохозяйственных предприятий Свердловской области. Обоснована государственная поддержка программ сельскохозяйственных кредитов и сбалансированного развития села.

Ключевые слова: сельскохозяйственное производство, убыточность производства, сбалансированная структура села, сельскохозяйственные кредить, финансовая поддержка сельскохозяйственного производства.

\section{S.V. Ilyukhina}

\section{FEATURES OF AGRICULTURAL LENDING IN THE SVERDLOVSK REGION}

Abstract: this paper justifies balanced policy of rural development through loan support programs for agricultural producers. The authors have analyzed the data on profit, loans and credits of 74 agricultural enterprises of the Sverdlovsk region and provided an obtained information in the article. They also have justified the state support of agricultural loans and balanced development of the village.

Keywords: agricultural production, loss of production, balanced structure of the village, agricultural loans, financial support for agricultural production.

Мотивация труда и экономические результаты в сельском хозяйстве прямо связаны с развитием социальной инфраструктуры. В системе факторов, влияющих на результативность производства, следует учитывать условия, определяемые социальной инфраструктурой. Институты социальной инфраструктуры создают 
предпосылки для расширенного воспроизводства рабочей силы и привлечения и закрепления квалифицированных специалистов. Наполненная социальная инфраструктура позволяет освободить работника от множества бытовых проблем, способствует личностному росту, предоставляет ему больше свободного времени, что в сумме обеспечивает его эффективное и мотивированное участие в хозяйственной деятельности [1, с. 249]. При этом комплексное развитие сельскохозяйственных территорий тормозится сезонностью и убыточностью производства.

Проблема безубыточности сельскохозяйственного производства актуальна для экономики во все времена, для всех стран. Создание экономического механизма оптимизации доходов и расходов сельхозпредприятий тесно связано с использованием заёмных средств.

Вопросы сельскохозяйственного кредитования были исследованы нами в Свердловской области. Проанализирована выборочная совокупность сельскохозяйственных предприятий - более $50 \%$ (74 предприятия), что удовлетворяет требованиям репрезентативности данных. Средняя прибыль сельхозпредприятия, обеспечивающая безубыточность составила 50569 тыс. руб. Из всей рассмотренной совокупности таковыми признаны $72 \%$, следовательно, убыточными являются 26-28\%, данные колеблются, так как некоторые хозяйствующие субъекты не предоставили информацию, некоторые их них закрылись. Убытки в среднем составили - 16024 тыс. руб. Следовательно, исходя из априорности убыточности ведения сельского хозяйства на территории рискового земледелия, к категории которой относится собственно Свердловская область, без дополнительного финансового рычага в виде заемных средств, выжить отрасли представляется затруднительным.

Сельхозпредприятия берут займы и кредиты в основном у других предприятий в денежном и в натуральном виде (так называемый товарный кредит): например, берут весной культуры для выращивания и отдают осенью после продажи. Средняя сумма займов одного сельхозпредприятия, 160590 тыс. руб.

Банки (по предоставленным данным) денежные кредиты сельхозпредприятиям не выдают вообще [4]. Однако, по нашему мнению, банковские кредиты 
некоторым сельхозпредприятиям все-таки выдаются на различных условиях, не зря ведь для этого существует поддержка государства. А данных нет, так как организации не обязаны выставлять свою кредитную историю, делают это только самые крупные промышленные предприятия.

Число кредитованных банками сельхоз предприятий совсем небольшое, потому что аграрная сфера в нашем регионе является рискованной деятельностью, что повышает риски невозврата ссуд, с чем кредитные организации не хотят иметь дело. Другие банки не выделяют особых кредитов для сельскохозяйственных предприятий. Их кредитуют на таких же условиях, как другие юридические лица.

В России государство оказывает поддержку сельскохозяйственным предприятиям, через банки: Альфа-Банк, Промсвязьбанк, Банк ВТБ, Газпромбанк, Райффайзенбанк, Росбанк, Банк «Открытие» [4].

Инвестиционные цели - финансирование мероприятий по приобретению основных средств, модернизации и реконструкции производства, запуску новых проектов/производств. Допускается финансирование текущих расходов, связанных с реализацией инвестиционного проекта (не более $30 \%$ от совокупной величины инвестиционных кредитов).

Проведенный структурный анализ данных по прибыли, займам и кредитам 74 сельскохозяйственных предприятий Свердловской области за 2013-2015 года выявил следующее [2].

На возмещение части процентной ставки по инвестиционным кредитам (займам) на развитие растениеводства, переработки и развития инфраструктуры и логистического обеспечения рынков продукции растениеводства от общей суммы идет 13\%, 73,9\% из федерального бюджета, 26,1\% из бюджета субъекта РФ. Возмещение части процентной ставки по инвестиционным кредитам (займам) на развитие животноводства, переработки её продукции, развития инфраструктуры и логистического обеспечения рынков продукции животноводства: $33,7 \%$ от общей суммы, 86,5\% от федерального бюджета, остальное от бюджета субъекта РФ. 
Возмещение части процентной ставки по инвестиционным кредитам (займам) на строительство и реконструкцию объектов молочного скотоводства: $6,6 \%$ от общей суммы, 63,9\% от федерального бюджета, 36,1\% от бюджета субъекта РФ. По краткосрочным кредитам (займам) на развитие животноводства, переработки и реализации продукции животноводства: $21,6 \%$ от общей суммы, 43,5\% от федерального бюджета, 56,5\% от бюджета субъекта РФ. По краткосрочным кредитам (займам) на развитие растениеводства, переработки и реализации продукции растениеводства: от общей суммы - 9,5\%, из федерального бюджета $64,7 \%$; на развитие молочного скотоводства - от общей суммы - 5,9\%, из федерального бюджета - 59,7\%, на переработку продукции растениеводства и животноводства в области развития оптово-распределительных центров - от общей суммы - 5,9\%, от федерального бюджета - 63,4\%; по долгосрочным, среднесрочным и краткосрочным кредитам, взятым малыми формами хозяйствования 2,9\%, от федерального бюджета 62,8\%.

Инвестиционные кредиты занимают 54,1\% от всех возмещений, краткосрочные кредиты - 42,9\%, что говорит о том, что государство поддерживает больше инвестиционные кредиты, направленные на развитие, а также краткосрочные кредиты (займы), направленные на развитие.

Все это относится к большим и средним формам хозяйствования. Поддержание малых форм хозяйствования по долгосрочным, среднесрочным и краткосрочным кредитам составляет всего 2,9\%, что говорит о том, что государственная поддержка на это не направлена.

Возмещение части процентной ставки по кредитам реализуется в большей степени за счёт средств федерального бюджета и составляет 68,3\%, остальное за счёт средств субъекта РФ. На развитие растениеводства возмещается - 23,3\%, животноводства - 30,7\%, молочного скотоводства - 12,5\%, переработки продукции растениеводства и животноводства $-5,9 \%$

Приведённые выше результаты аналитических расчётов позволяют с уверенностью утверждать, что в Свердловской области государственная поддержка 
направлена в основном на развитие животноводства и растениеводства, что составляет 54\% от общей суммы по возмещению процентной ставки. На развитие производства молочной продукции 12,5\%. На развитие переработки продукции растениеводства и животноводства 5,9\% от общей суммы возмещения процентной ставки. Направление государственной поддержки в большей степени на животноводства, далее растениеводства; в меньшей степени на молочное скотоводство, и совсем небольшой процент приходится на поддержку малых форм хозяйствования. Возмещения происходят в основном за счёт федерального бюджета. Всё это безусловно способствует не только развитию производства на селе, но и формирует благоприятную социальную инфраструктуру [2, с. 14], укрепляя экономическую мотивацию населения.

\section{Сиисок литературы}

1. Илюхин А.А. Социальная инфраструктура и трудовые ресурсы сельских территорий / А.А. Илюхин, С.В.Илюхина // Экономика региона. - 2011. - №4. C. 249-253.

2. Лавров В.Н. Перспективы взаимодействия социальной инфраструктуры и трудового потенциала села / В.Н. Лавров, С.В. Илюхина // Челябинский гуманитарий. - 2009. - Т. 1. - №7. - С. 14-20.

3. Сетевое издание «Информационный ресурс СПАРК» [Электронный ресурс]. - Режим доступа: https://www.spark-interfax.ru/promo/

4. Министерство сельского хозяйства Свердловской области [Электронный pecypc]. - Режим доступа: http://gp.specagro.ru/region/66

Илюхина Светлана Викторовна - канд. экон. наук, доцент кафедры статистики, эконометрики и информатики ФГБОУ ВО «Уральский государственный экономический университет», Россия, Екатеринбург.

Ilyukhina Svetlana Viktorovna - candidate of economic sciences, associate professor of Statistics, Econometrics and Computer Science Department FSBEI of HE "Ural State University of Economics", Yekaterinburg, Russia. 